\title{
Sweeper tentacles of the brain coral Platygyra daedalea: induced development and effects on competitors
}

\author{
Einat D. Lapid ${ }^{1}$, Jeffrey Wielgus ${ }^{1}$, Nanette E. Chadwick-Furman ${ }^{1,2, *}$ \\ ${ }^{1}$ Interuniversity Institute for Marine Science, PO Box 469, Eilat, Israel and Faculty of Life Sciences, Bar Ilan University, \\ Ramat Gan, Israel \\ ${ }^{2}$ Present address: Biological Sciences Department, 101 Rouse Life Sciences Building, Auburn University, Auburn, \\ Alabama 36849-5407, USA
}

\begin{abstract}
Benthic marine organisms utilize an array of defensive and aggressive mechanisms that affect competition for space on hard marine substrata. The sweeper tentacles of stony corals are inducible aggressive organs used during competition, but they also may serve a pre-emptive defensive function. About half of the colonies of the brain coral Platygyra daedalea at Eilat, northern Red Sea, possess sweeper tentacles, many of which are not directed toward neighboring corals. These randomly oriented sweeper tentacles may be produced in order to detect the settlement or advance of corals occurring at $>5 \mathrm{~cm}$ distance from the colony. Of coral colonies $<5 \mathrm{~cm}$ distant from $P$. daedalea, about $43 \%$ exhibit tissue damage facing the interaction area. Adjacent corals with the most damage belong to the genera Favites and Leptastrea, while colonies of Millepora and congeneric Platygyra exhibit significantly less damage. Tissue damage of neighboring coral colonies decreases significantly with increasing distance from $P$. daedalea. The presence of sweeper tentacles on brain corals correlates significantly with colony diameter, but not with the number of neighboring colonies. The aggressive reach of $P$. daedalea in Eilat is $5.3 \pm 3.0 \mathrm{~cm}$, longer than previously reported for members of this genus. Under laboratory conditions, sweeper tentacles develop on $P$. daedalea colonies about $30 \mathrm{~d}$ following initial contact with colonies of the common massive coral $F$. complanata, and at approximately $50 \mathrm{~d}$ they reach a maximum length of about $6.5 \mathrm{~cm}, 10 \times$ longer than feeding tentacles. Sweeper tentacles cause increasing tissue damage to F. complanata colonies over 2 mo. During morphogenesis, their tip-to-stalk ratio and ectoderm thickness doubles, indicating acrosphere development, but maximal width of the tentacle stalk does not change. Sweeper tentacles appear to be a common agonistic mechanism among stony corals, and may serve also as a defensive mechanism that allows the persistence of some species in crowded reef habitats.
\end{abstract}

KEY WORDS: Competition $\cdot$ Reef coral $\cdot$ Aggression $\cdot$ Defense $\cdot$ Behavior $\cdot$ Eilat $\cdot$ Red Sea

\section{INTRODUCTION}

Benthic marine organisms such as bryozoans, tunicates and macroalgae deploy a wide array of mechanisms to aggressively acquire living space on hard marine substrata, as well as to defend themselves from overgrowth (reviewed by Karlson 1999). Such mechanisms, coupled with the long lifespans of some colonial marine invertebrates, may result in the persistence of successful species and the development of stable communities in some benthic marine habitats
(Karlson 1999). On coral reefs, interactions between stony corals can cause standoffs that involve the cessation of growth and maintenance of stable space-use patterns for long periods covering several years, which then may be interrupted by large-scale physical disturbances (Connell 1976). In spite of the importance of competitive interactions among stony corals in crowded shallow marine habitats, much remains unknown about the extent to which particular mechanisms function in aggression versus defense of living space. 
Capture of living space by stony corals occurs via settlement of planula larvae, budding of polyps, or fragmentation of the calcareous skeleton (Connell 1973). Due to limited availability of hard substrate, coral growth either 2-dimensionally across the substrate or 3-dimensionally into the water column may create crowded conditions in which coral colonies compete with each other for space (Connell 1973, 1976, Porter 1974, den Hartog 1977, Lang \& Chornesky 1990). Corals compete with each other indirectly via overtopping, whereby one colony overshadows another and thus presents sufficient light or water flow from reaching its opponent, or directly, whereby corals contact and damage the soft tissues of opponents (Connell 1973, Purkis \& Riegel 2004). Stony corals have developed an array of mechanisms to injure their neighbors and clear space for further colony growth, including (1) extracoelenteric digestion, whereby the mesenterial filaments normally used for feeding serve as aggressive organs and digest the tissues of adjacent corals (Lang 1973), (2) unusually elongated polyps termed 'sweeper polyps', which are used by only a few genera of corals to damage their neighbors (Peach \& Guldberg 1999), (3) secretion of a thick layer of mucus containing numerous nematocysts that cause necrosis and sloughing in neighboring corals, used mainly by fungiid corals (Chadwick 1988), and (4) sweeper tentacles, which are elongate tentacles that develop from normal feeding tentacles (Hidaka \& Yamazato 1984).

Sweeper tentacles were believed originally to be specialized feeding organs (Lewis 1975), but have never been observed to function in food capture, even though such behavior has been searched for (Chornesky 1983). They are now considered to be specialized competitive organs, as first suggested by den Hartog (1977). They occur mainly in scleractinian corals (reviewed by Williams 1991), but also have been observed in antipatharian black corals (Goldberg et al. 1990) and gorgonian sea fans (Sebens \& Miles 1988). Sweeper tentacles are induced to form in response to contact with the tissues of opponent tentacles or mesenterial filaments, but not necessarily as a result of tissue damage (Chornesky 1983). It is not fully clear whether sweeper tentacles are defensive or aggressive organs, but they are believed to be homologues to the catch tentacles of sea anemones (Williams 1991) and the bulbous marginal tentacles of corallimorpharians. The latter organs develop following contact with an array of cnidarians (Langmead \& Chadwick-Furman 1999), and are known to act in aggressive-defensive interactions during competition for space on coral reefs.

Sweeper tentacles were described first by den Hartog (1977) as being 3 to $5 \times$ longer than regular feeding tentacles, more opaque, and with aberrantly enlarged acrospheres. Similar descriptions were published by
Richardson et al. (1979), Chornesky (1983) and Hidaka \& Yamazato (1984) for various coral species. In addition to their unique shape, sweeper tentacles differ from feeding tentacles in the composition of their nematocysts and in their nematocyst-to-spirocyst ratio. Intermediate forms, in terms of tentacle shape and nematocyst composition, are recognized between feeding tentacles and sweeper tentacles. Sweeper tentacles are not invariant structures, but have the ability to revert back to feeding tentacles over several weeks if contact between opponent corals ceases (den Hartog 1977, Wellington 1980, Hidaka \& Yamazato 1984).

The morphogenesis of sweeper tentacles occurs over several weeks following the initiation of contact with certain cnidarian competitors. This process requires about $30 \mathrm{~d}$ in the reef-building coral Agaricia agaricites (Chornesky 1983) and 30 to $60 \mathrm{~d}$ in the coral Pocillopora damicornis/P. robusta (Wellington 1980). During field experiments on the development of bulbous marginal tentacles in corallimorpharians that contacted colonies of the brain coral Platygyra lamellina, the $P$. lamellina colonies developed sweeper tentacles within about $21 \mathrm{~d}$ following initial contact (Langmead \& Chadwick-Furman 1999).

In coral species with the potential to develop sweeper tentacles, not every colony or every polyp within a colony produces them. It is believed that the presence of specific stimuli (i.e. contact with opponent tissues) determines their location on a given colony (Chornesky 1983). In the reef-builder Montastraea cavernosa, sweeper tentacles may develop on the side of the colony most exposed to water flow (den Hartog 1977). At some reef locations, $M$. cavernosa possess sweeper tentacles on the colony periphery only, while at other locations, they may occur on all polyps in the colony (Richardson et al. 1979). Colonies of the coral Agaricia agaricites develop sweeper tentacles only on the area adjacent to colonies of other coral species (Chornesky 1983). On Pocillopora spp. corals, they develop on regenerating tissue following attack by mesenterial filaments from neighboring corals (Wellington 1980). Little is known about the frequency of occurrence of sweeper tentacles in most of the coral species that possess them, their location on the colony, possible use as a pre-emptive mechanism, ecological impacts on competitors, or quantification of the morphogenetic process.

The first attempt to establish a hierarchy of aggression among corals was made by Lang (1971) on Atlantic corals and was based on the destructive abilities of mesenterial filaments. This hierarchy was linear (transitive $=\mathrm{A}>\mathrm{B}>\mathrm{C}$ ), with predictable results. Lang (1971) concluded that slow-growing massive corals are more aggressive than fast-growing corals. Since then, research has shown that many coral interactions are not 
transitive, and that in different regions (e.g. Atlantic, Pacific, Red Sea), different hierarchies may prevail. The outcomes of interactions are not always predictable, and depend on the use of several types of competitive mechanisms (including sweeper tentacles) and on seasonal environmental changes and unexpected disturbances (Connell 1973, Cope 1981, Abelson \& Loya 1999, Purkis \& Riegel 2004). An important environmental factor influencing the effectiveness of sweeper tentacles is the level of water motion; high flow may deflect these elongated tentacles and allow rapid tissue recovery of subordinate corals (Genin \& Karp 1994).

The abundance of coral species on the reef does not necessarily vary with their level of aggressiveness. In the Caribbean Sea, Lang (1970) found that the most aggressive corals belong to the rarest species, while in the Indian Ocean, Sheppard (1979) observed that highly aggressive corals monopolize some reef areas. In the Red Sea, no clear connection has been found between coral aggressiveness and abundance (Abelson \& Loya 1999).

About 13 species of scleractinian corals have been reported to possess sweeper tentacles (Williams 1991). Members of the genus Platygyra (brain corals) are known to develop sweeper tentacles (Langmead \& Chadwick-Furman 1999), but no published information exists concerning the process of morphogenesis or ecological effects on the reef. The use of sweeper tentacles by Platygyra spp. may have an important effect on coral community structure due to the abundance of members of this genus in some reef areas (Abelson \& Loya 1999).

The 11 known species within the genus Platygyra are mostly meandroid. The colonies are massive, dome-shaped or flat, and extend their tentacles only at night (Veron 2000). On the Great Barrier Reef of Australia, 7 morphological species of Platygyra are recognized (Veron 1986), but genetic analysis has revealed no more than 1 genetic grouping, indicating possibly incomplete reproductive isolation and hybridization among the existing species (Miller \& Benzie 1997). Of the organisms occupying space on reefs at Eilat, northern Red Sea, stony corals, soft corals and algae are the major components (Benayahu \& Loya 1981). According to line transects surveyed by Abelson \& Loya (1999), $P$. lamellina is abundant at most depths in Eilat, but is concentrated mainly in shallow water, and is ranked as intermediate in aggressiveness. A survey conducted by Glassom (2002) in shallow water at Eilat also showed that Platygyra spp. are among the most abundant corals, occurring at 1.2 to 4.2 colonies $\mathrm{m}^{-2}$, with the largest observed colony measuring about $72 \mathrm{~cm}$ diameter.

Preliminary surveys for the present study revealed that colonies of Platygyra daedalea are much more common than those of $P$. lamellina on a reef examined at Eilat, as indicated by Sheppard \& Sheppard (1991) for the Red
Sea in general. Colonies of $P$. daedalea are distinguishable from those of $P$. lamellina by having valleys wider than the separating walls, and angular sharp walls with irregular exsert septa (Sheppard \& Sheppard 1991).

Several open questions remain concerning the function and morphogenesis of sweeper tentacles in stony corals. The extent to which these tentacles are developed and maintained without the presence of nearby coral competitors is unknown, as well as their potential role as pre-emptive defensive organs for detecting the settlement or advance of corals at some distance $(>5 \mathrm{~cm})$ from the colony. In addition, tissue-level morphological changes during their morphogenesis and regression have not been described quantitatively. Finally, for the common brain coral genus Platygyra, no published information exists concerning the abundance or distribution of sweeper tentacles on colonies in the natural reef habitat, or variation in their effects among the types of coral competitors contacted. We report here on variation in the occurrence of sweeper tentacles on $P$. daedalea with colony size, crowding conditions, and the extent of damage to neighboring corals. We also describe the induced development of sweeper tentacles from feeding tentacles, and quantify changes in tentacle morphology in terms of elongation, acrosphere development and ectoderm thickness. Finally, we assess short-term effects on a common competitor, the massive coral species Favites complanata.

\section{MATERIALS AND METHODS}

Field observations. We used a band transect method to survey $171 \mathrm{~m}^{2}(85.5 \times 2 \mathrm{~m})$ on the shallow reef adjacent to the Interuniversity Institute for Marine Science (IUI) at Eilat, northern Red Sea, in an area with abundant colonies of the brain coral Platygyra daedalea ( $\mathrm{N}=10$ transects of 5 to $20 \mathrm{~m}$ length each). The transects were deployed at a depth of 2 to $3 \mathrm{~m}$ parallel to the shore, and each square meter was examined until a total of 100 colonies of $P$. daedalea had been observed. The following information was recorded for each colony: diameter, height, skeletal distance to each neighboring stony coral (up to $5 \mathrm{~cm}$ distance), genus of neighboring corals, damage distance (= aggressive reach, i.e. the distance between live tissues of interacting corals, after Sheppard 1981), direction of damage (on P. daedalea, or neighbor, or both), and other observations (any special type of damage or overgrowth). Each colony was then marked with a small buoy, and during night dives each was examined to determine the number and length of all sweeper tentacles and their location on the colony (facing neighboring corals or not).

Chi-square tests were applied to compare the frequencies of tissue damage on neighboring corals at 
various distances from the brain corals, the proportion of interactions with sweeper tentacles among neighboring coral genera and with distance from the brain corals, and the susceptibility to damage of the various genera of neighboring corals. Whenever significant differences were found, we used a posthoc Tukey test on log-transformed values to explore where the differences were. Logit regression was used to test the presence of sweeper tentacles versus colony diameter and their presence versus number of neighboring colonies.

Laboratory experiment. To quantify the process of induced development of sweeper tentacles, an experiment was conducted under laboratory conditions at the Underwater Observatory Marine Park in Eilat, adjacent to the IUI. We brought each of 10 colonies of Platygyra daedalea into tentacle contact (1 $\mathrm{cm}$ apart when tentacles were contracted) with a colony of the common massive coral Favites complanata. As a control, 10 colonies of each species were isolated from contact (at least $5 \mathrm{~cm}$ apart when tentacles were fully extended). Treatment and control colonies were interspersed randomly among 3 aquaria $(48 \times 50 \times 40 \mathrm{~cm}$ each) supplied with running seawater. Illumination was by Philips $36 \mathrm{w} / \mathrm{w}$ blue type light bulbs suspended over each aquar-

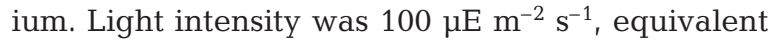
to the light level at approximately $15 \mathrm{~m}$ depth. All colonies were observed at 3 to 4 night intervals for a period of $78 \mathrm{~d}$, until sweeper tentacles were fully developed. During each observation, the lengths of the 3 longest tentacles were recorded at 2 locations on each treatment colony: (1) the side facing an adjacent coral ${ }_{i}(2)$ the opposite side not facing an adjacent coral. On isolated control coral colonies, 2 arbitrary opposing sides were examined. The total number of sweeper tentacles observed on each colony was also recorded. Sweeper tentacles were defined as long tentacles possessing an enlarged tip relative to the stalk (den Hartog 1977, Hidaka \& Yamazato 1984), in contrast to feeding tentacles, which were defined as short, tapered tentacles. Another feature of feeding tentacles is the batteries of nematocysts along the stalk, whereas the stalk of sweeper tentacles appears smooth (Fig. 1a). All tentacle measurements were conducted using a fine flexible ruler, made of transparent underwater paper and marked in millimeters.

Each week for the first $8 \mathrm{wk}, 3$ to 5 of the longest tentacles from each of 3 experimental and 3 control colonies of Platygyra daedalea were removed using fine forceps. Approximately 10 tentacles were measured from each treatment each week; thus each colony was sampled $\leq 3$ times to minimize effects on the results (modified after Langmead \& Chadwick-
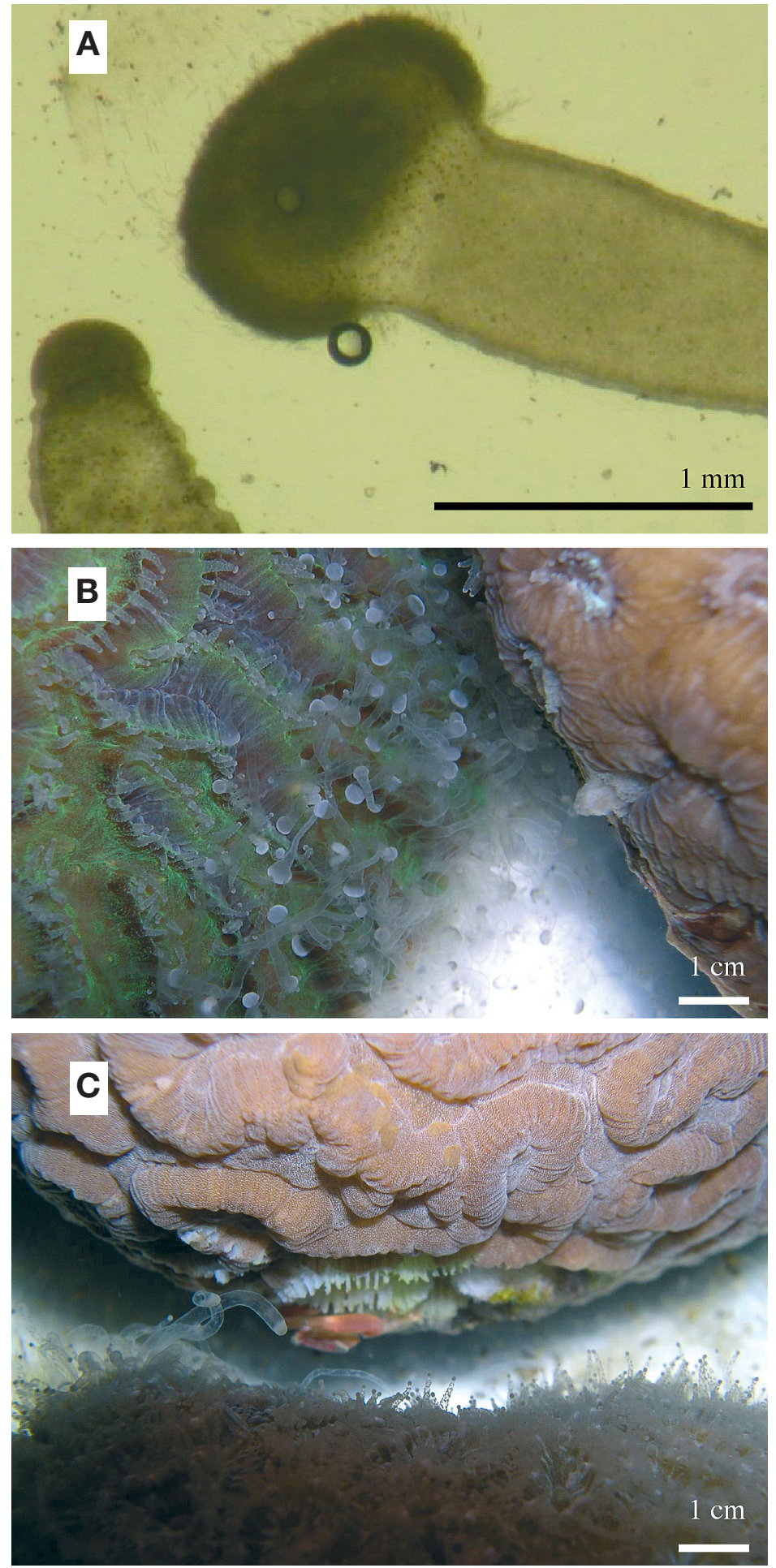

Fig. 1. Platygyra daedalea. (A) Sweeper (upper right) and feeding (lower left) tentacles of brain coral at Eilat, northern Red Sea. (B) Colony (left) with many sweeper tentacles near area of experimental contact with colony of Favites complanata; note feeding tentacles in upper left of photograph for comparison. (C) Sweeper tentacles of F. complanata (lower left) in comparison to feeding tentacles (lower right), note exposed skeleton and tissue damage on colony of $P$. daedalea (upper center) 
Furman 1999). Each excised tentacle was placed in $7.5 \% \mathrm{MgCl}_{2}$ in 1:1 distilled water: seawater for $30 \mathrm{~min}$. Then, fresh preparations were made by transferring each tentacle to a separate glass slide with 2 drops of filtered seawater, and gently applying a coverslip without further squashing (after Langmead \& Chadwick-Furman 1999). The preparations were examined under a binocular microscope at 50× magnification. In order to quantify morphological changes, the following parameters were recorded using a calibrated eyepiece reticule: (1) width of tentacle at tip $(0.1 \mathrm{~mm}$ from the tip); (2) width of tentacle at stalk (1 $\mathrm{mm}$ from the tip); (3) thickness of ectoderm layer at the tip; (4) thickness of ectoderm layer at the stalk. In order to examine the development of acrospheres (enlarged tentacle tips which distinguish feeding tentacles from sweeper tentacles), the ratio of tip to stalk widths was calculated (after Langmead \& Chadwick-Furman 1999).

Observations to assess tissue damage on the corals were also made each week for the duration of the experiment (after Romano 1990). Damage was calculated as the area of an ellipse of exposed skeleton along the interacting margins of the experimental colonies.

Results are presented as means $\pm 1 \mathrm{SD}$, except where indicated.

\section{RESULTS}

\section{Field observations}

Colonies of Platygyra daedalea were common on the shallow reef slope at the IUI, occurring at an abundance of $0.67 \pm 0.27$ colonies per $\mathrm{m}^{2}$ ( $\mathrm{N}=10$ transects).

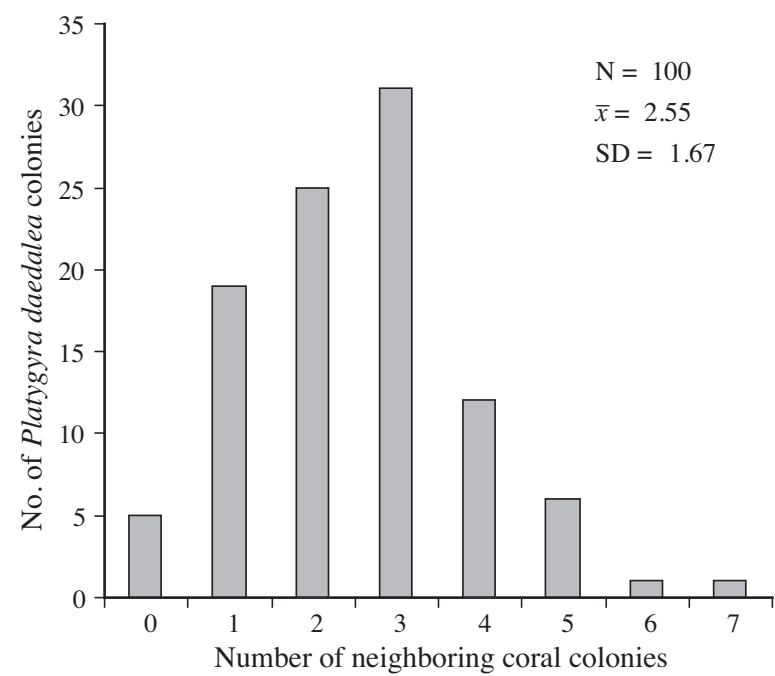

Fig. 2. Number of stony coral colonies adjacent to each colony of Platygyra daedalea ( $\leq 5 \mathrm{~cm}$ distance) at 2 to $3 \mathrm{~m}$ depth on reef slope adjacent to Interuniversity Institute for Marine Science, Eilat, northern Red Sea
Almost all were in contact with neighboring corals, and some had up to 7 neighbors (Fig. 2). Overall, the 100 observed colonies of $P$. daedalea contacted 255 colonies of other stony corals.

The most commonly contacted stony corals were members of the genera Favia, Favites and Stylophora (Fig. 3A). Few interactions occurred with colonies of Acropora and Cyphastrea, although they were common on the reef examined. The percent of interactions in which damage was observed on contacted corals yaried as a function of coral genus (chi-square test, $\chi^{2}=28.47$, $\mathrm{df}=8$, $\mathrm{p}<0.001$, Fig. 3B). Corals facing Platygyra daedalea with the most damage were those of the genera Favites and
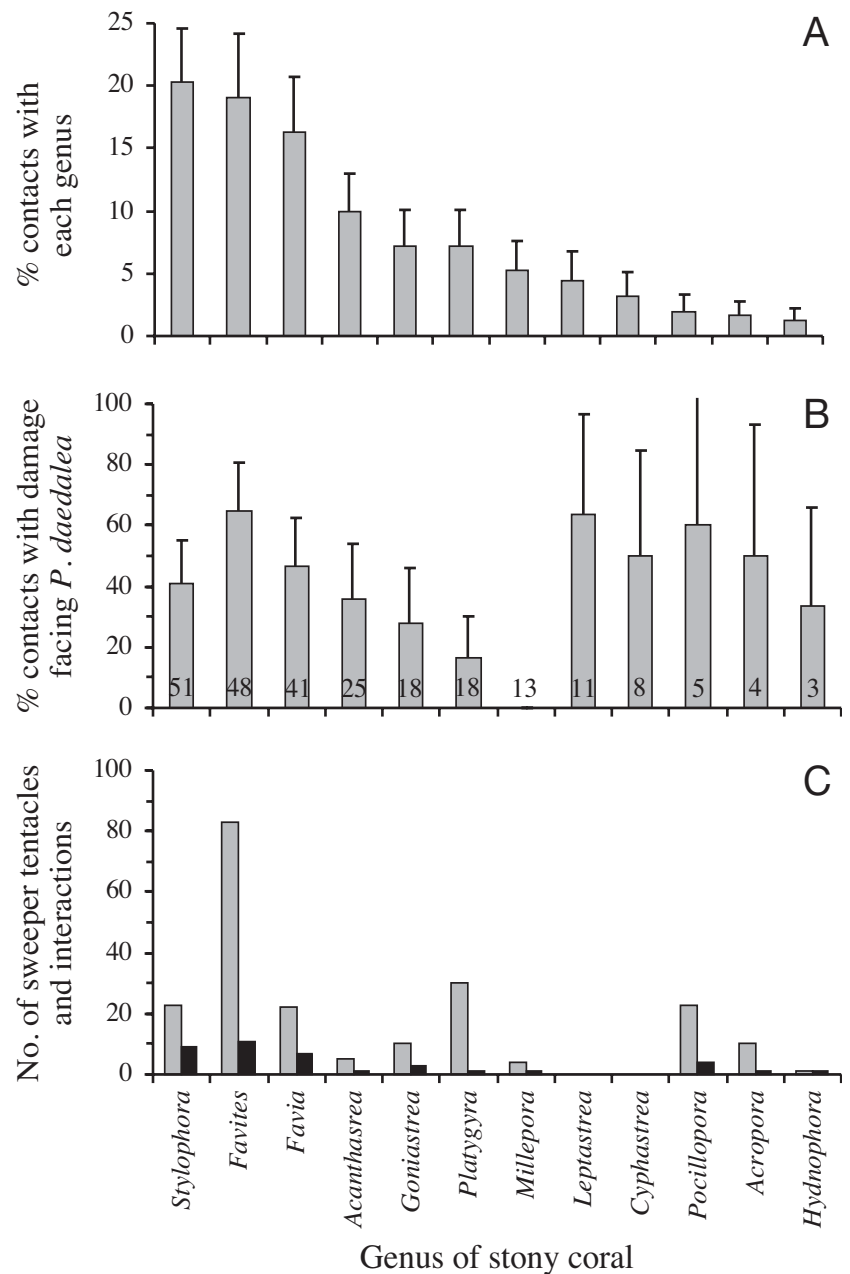

Fig. 3. Platygyra daedalea. Contacts between colonies of brain coral and other stony coral genera at Eilat, northern Red Sea; 100 colonies examined, which contacted 255 colonies of other species of stony corals. (A) Percent (95\% CI) of contacts with each coral genus. (B) Percent $(95 \%$ CI) of contacts in each genus with damage on side facing $P$. daedalea; number at base of each bar represents number of colonies of each genus contacting $P$. daedalea. (C) Total number of sweeper tentacles observed on $P$. daedalea colonies in contact with each coral genus (grey bars), and total number of interactions in which sweeper tentacles were observed (black bars) 
Leptastrea. Among the 8 most frequently contacted coral genera, colonies of Millepora and those of the congeneric Platygyra exhibited significantly less damage than did other genera (Tukey test, Fig. 3B).

Most cases in which sweeper tentacles were observed on the brain corals involved interactions (black bars in Fig. 3C) with the corals Favites, Favia and Stylophora. Large numbers of sweeper tentacles were observed in cases where Platygyra daedalea contacted members of these 3 genera, plus those of Pocillopora and congeneric Platygyra. By far the most sweeper tentacles (grey bars in Fig. 3C) were directed toward Favites corals.

Damage to neighboring coral colonies decreased significantly with increasing distance from Platygyra daedalea colonies (chi-square test, $\chi^{2}=22.60$, df $=3$, $\mathrm{p}<0.001) ; 3 \mathrm{~cm}$ appeared to be a critical distance, above which damage to neighbors was significantly reduced (Tukey test, Fig. 4). In interactions between $P$. daedalea and the 3 most frequently-contacted coral genera (Favia, Favites, and Stylophora), there were similar trends of decreasing damage with increasing distance, and in some cases of a decreasing number of sweeper tentacles on the brain corals (Fig. 5). However, the number of interactions with sweeper tentacles did not vary significantly as a function of distance from neighbors (chi-square test, $\chi^{2}=5.11, \mathrm{df}=3, \mathrm{p}>0.16$ ).

Sweeper-tentacle presence on colonies of Platygyra daedalea depended on colony diameter $(\mathrm{p}<0.008)$. Brain corals that possessed sweeper tentacles were significantly larger $(21.5 \pm 11.7 \mathrm{~cm})$ than those without $(15.2 \pm 9.7 \mathrm{~cm})$. In contrast, the presence of sweeper tentacles did not depend on the number of neighbor-

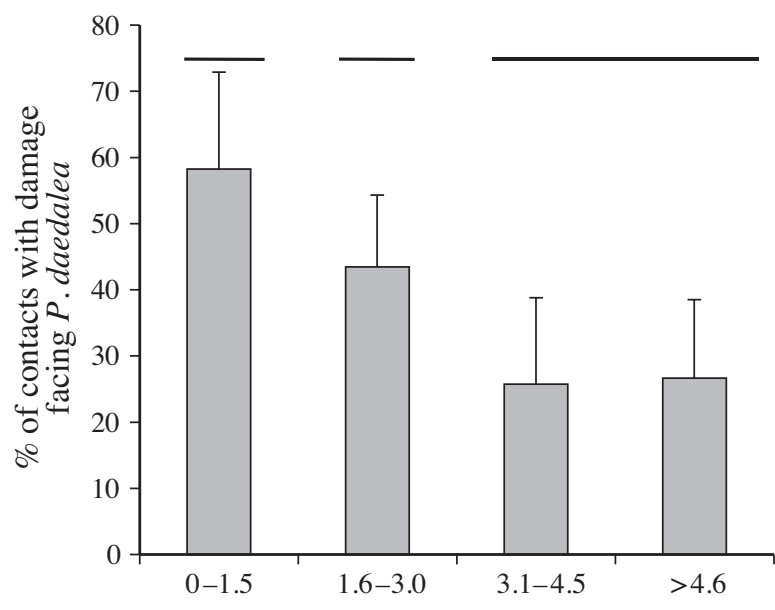

Distance from $P$. daedalea colonies $(\mathrm{cm})$

Fig. 4. Variation $(+95 \% \mathrm{CI})$ in damage to stony corals as a function of distance from colonies of Platygyra daedalea at Eilat, northern Red Sea. Bars connected by lines are not significantly different from each other (chi-square test, $\chi^{2}=$ 22.60, $\mathrm{df}=3, \mathrm{p}<0.001$, followed by Tukey test for unequal sample sizes)

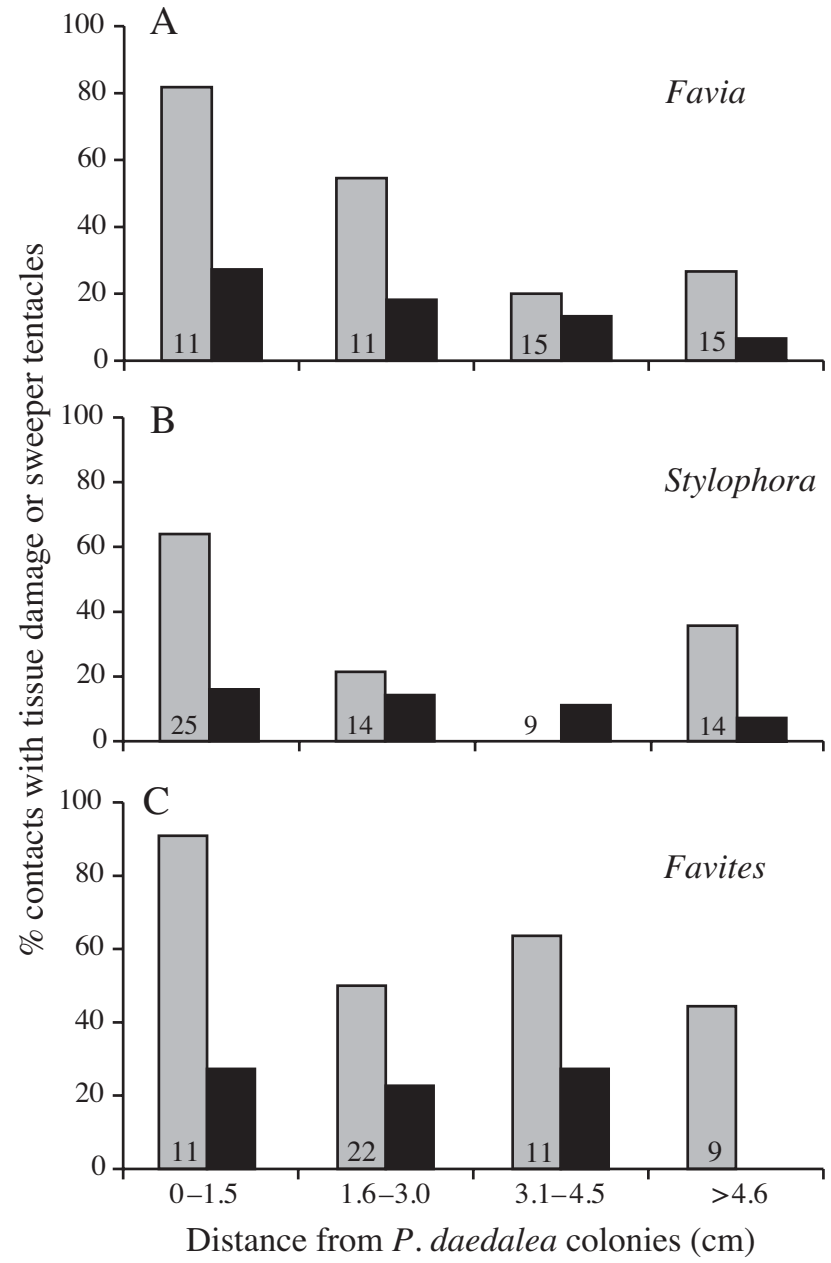

Fig. 5. Variation in damage (grey bars) and sweeper tentacles (black bars) with distance from colonies of Platygyra daedalea, for 3 most frequently contacted coral genera at Eilat, northern Red Sea. Values inside bars: number of colonies

ing coral colonies (logit regression analysis, $\mathrm{p}>0.78$ ). The proportion of interactions with sweeper tentacles varied significantly with the type of coral genus contacted (chi-square test, $\chi^{2}=29.11, \mathrm{df}=11, \mathrm{p}<0.002$ ), indicating that some coral genera elicited more sweeper tentacle development than others (cf. Fig. 3A and C).

Almost half of all Platygyra daedalea colonies observed $(43.4 \%, \mathrm{~N}=100)$ possessed sweeper tentacles. About half of these, or $21.2 \%$ of all colonies, possessed randomly-directed sweeper tentacles (not facing toward neighboring corals). Of the 252 observed interactions, sweeper tentacles were directed toward neighboring corals in about $15 \%$ of cases.

The aggressive reach of Platygyra daedalea (see 'Materials and methods') was $5.3 \pm 3.0 \mathrm{~cm}$, and the lengths of sweeper tentacles observed on $P$. daedalea colonies in the field ranged between 2 and $11 \mathrm{~cm}$ $(5.0 \pm 2.9 \mathrm{~cm})$. In some cases, corals of other genera also possessed sweeper tentacles on the area facing 
P. daedalea, especially colonies of Acanthastrea, Goniastrea and Favia. Colonies of brain corals showed tissue damage on the side facing neighbors in only $8.7 \%$ of interactions $(\mathrm{N}=252)$. Almost half $(42.8 \%)$ of the coral colonies adjacent to $P$. daedalea exhibited tissue damage facing the interaction area. The total number of sweeper tentacles directed toward neighbors was 409 , while the number of sweeper tentacles not directed toward neighboring corals was 147 .

\section{Laboratory experiment}

During the $78 \mathrm{~d}$ of the laboratory experiment, tentacles of experimental Platygyra daedalea colonies increased significantly in length on the side facing other corals (Pearson's correlation coefficient, $r=0.96$, $\mathrm{p}<0.001$, Fig. 6B). No significant change in length was observed in tentacles of the same colonies that did not face other corals $(r=0.37, p>0.05$, Fig. 6B), nor on either side of the control $P$. deadalea colonies isolated from contact (Fig. 6A). The time to initiation of tentacle growth, rate of growth and maximum tentacle length at the end of the experiment all varied substantially between corals in the treatment group. Some corals began to elongate their tentacles almost immediately (in $<10 \mathrm{~d}$ ), while others began this process only after $45 \mathrm{~d}$ or more. In only 1 of the 10 control colonies did tentacles change substantially in length. Slight variations in tentacle length ( \pm 1 to $2 \mathrm{~mm}$ ) between nights were observed on all corals, due to differences in their state of expansion between nights.

The ratio of the tip-to-stalk width in tentacles facing other corals increased significantly during the first $56 \mathrm{~d}$ of the experiment (Pearson's correlation coefficient, $\mathrm{r}=$ 0.97, p $<0.0001$, Fig. 7A). The mean ratio at the start was $0.65 \pm 0.14$, indicating tapered tentacle tips that were narrower than the stalk. After $56 \mathrm{~d}$, the tip-tostalk ratio had doubled $(1.35 \pm 0.29)$, indicating that tentacles had developed swollen bulb-like acrospheres (Figs. 1A \& 7A). The tip-to-stalk ratio of tentacles on isolated corals did not increase significantly over time; it was $0.63 \pm 0.05$ at the start and $0.76 \pm 0.15$ at the end of the experiment $(r=0.18, p>0.05$, Fig. 7A). There was no significant difference in the tip-to-stalk ratio of tentacles on control versus experimental colonies at the start of the experiment (2-sample $t$-test, $t=0.156$, $\mathrm{df}=18, \mathrm{p}>0.05)$, but after $56 \mathrm{~d}$ the difference was significant (2-sample $t$-test, $t=5.6, \mathrm{df}=18, \mathrm{p}<0.0001$ ).

Tentacle stalk diameter at the widest point measured (approximately $1 \mathrm{~mm}$ from the tip) did not vary between feeding and sweeper tentacles (2-sample $t$-test, $\mathrm{p}>0.1,677 \pm 173$ and $772 \pm 321 \mu \mathrm{m}$ respectively). However, due to the tapering effect (Fig. 1A), the area with the widest diameter on the feeding tentacles was
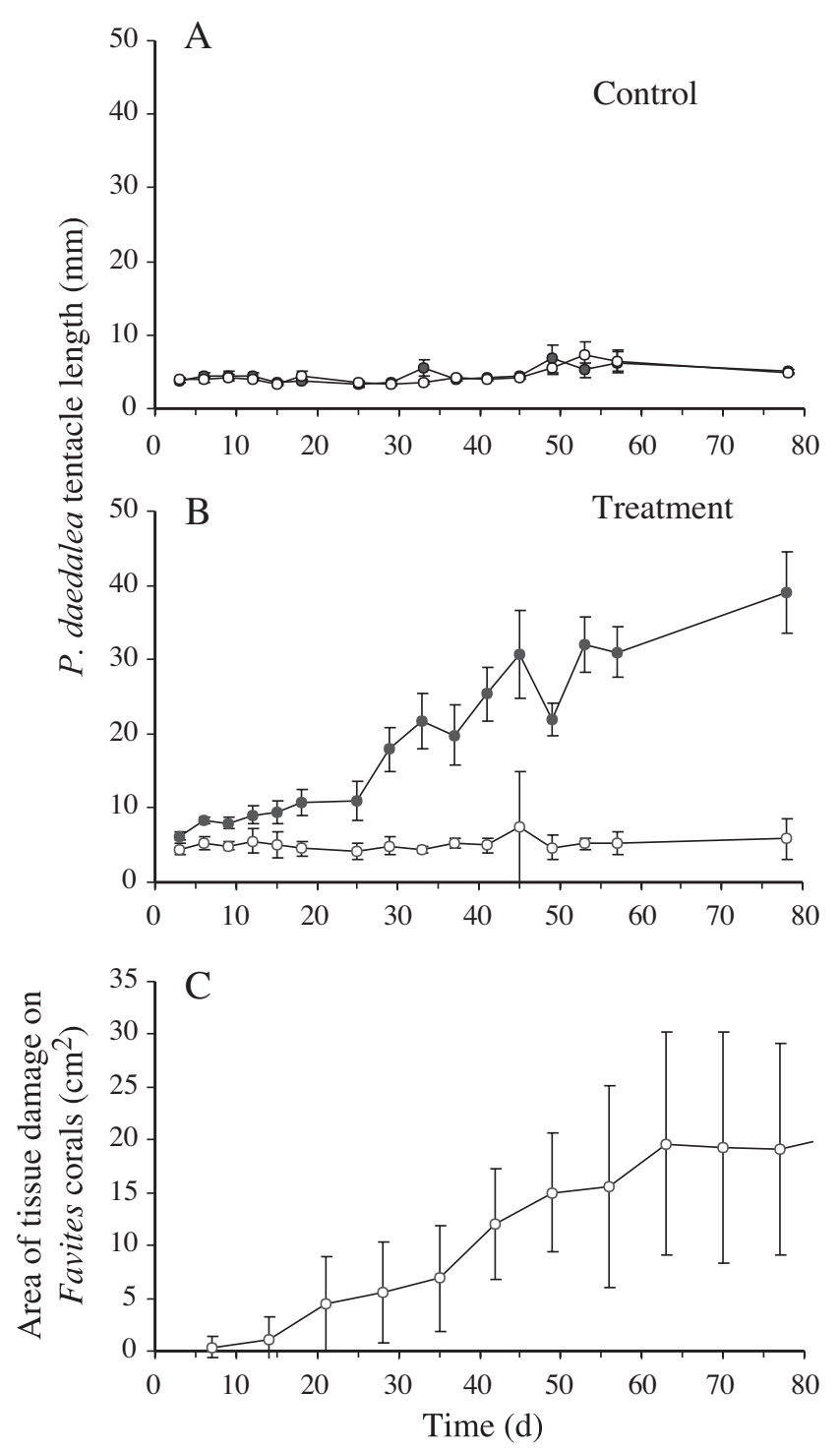

Fig. 6. Platygyra daedalea. Variation in mean $( \pm \mathrm{SD})$ tentacle length and area of tissue damage of Favites complanata with time following initiation of experimental contact between colonies of $P$. daedalea and $F$. complanata under laboratory conditions. (A) Tentacle length of control P. daedalea corals not in contact with F. complanata; (•) (O) 2 opposite sides of colony $(\mathrm{N}=10)$. (B) Tentacle length of experimental $P$. daedalea colonies on side facing $F$. pentagona colonies $(\bullet)$, and on side not facing contact $(\mathrm{O})(\mathrm{N}=10)$. (C) Area of exposed skeleton (tissue damage) on colonies of $F$. complanata facing $P$. daedalea $(\mathrm{N}=9)$

near the tentacle base. This area was not always measurable due to the technical difficulties of removing tentacles from live, unanesthetized coral colonies.

Ectoderm thickness at the tentacle tips did not vary significantly with time in either group. Experimental colonies began with an ectoderm thickness of $102 \pm$ $42 \mu \mathrm{m}$ and reached a thickness of $134 \pm 36.6 \mu \mathrm{m}$, with large variation during the intermediate stages (Pearson's correlation coefficient, $r=0.628, \mathrm{p}>0.05$, 

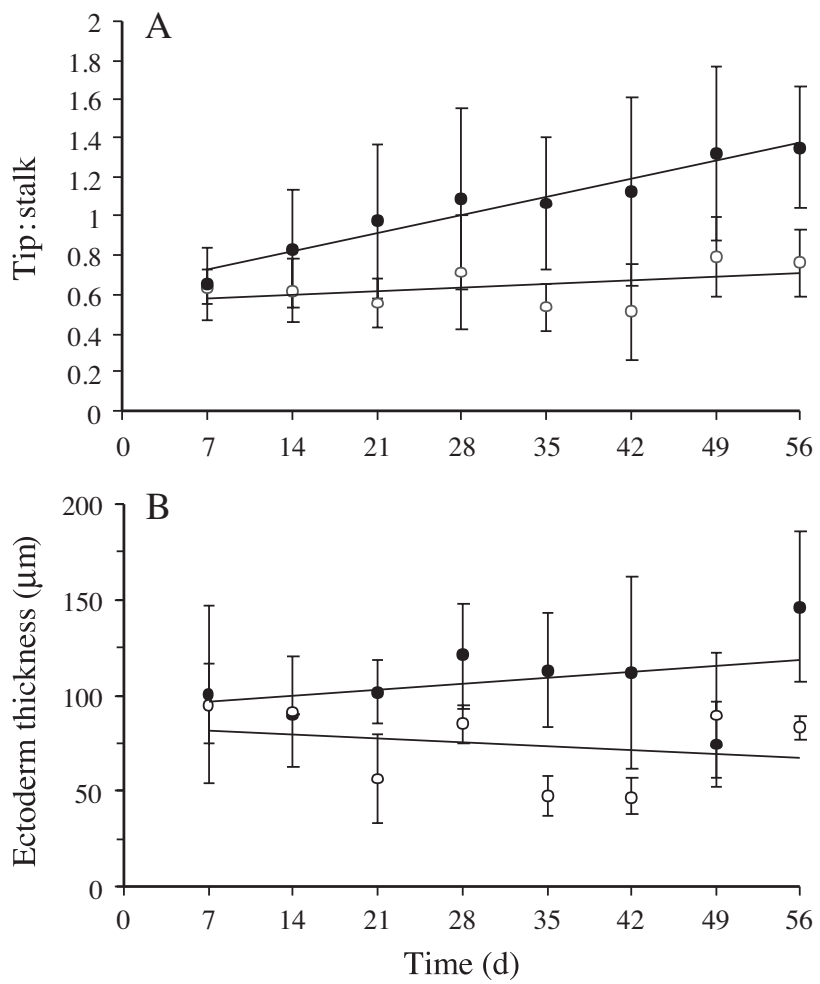

Fig. 7. Platygyra daedalea. Mean $( \pm \mathrm{SD})$ variation in 2 measures of tentacle shape over time in colonies of brain coral in laboratory experiment. (A) Tip-to-stalk width ratio; (B) ectoderm thickness at tentacle tip. $(\bullet)$ tentacles of colonies taken from side facing colonies of stony coral Favites complanata; (O) tentacles taken from isolated colonies

Fig. 7B). The ectodermal thickness of tentacle tips on control colonies was $88.0 \pm 28.6 \mu \mathrm{m}$ at the start and $82.0 \pm 17.5 \mu \mathrm{m}$ at the end of the experiment, also with large between-week variation. This parameter did not vary between the 2 groups at the start of the experiment (2-sample $t$-test, $t=0.862, \mathrm{df}=18, \mathrm{p}>0.05$ ), but after $56 \mathrm{~d}$ the experimental corals had a significantly thicker ectodermal layer in their tentacle tips than did the control corals (2-sample $t$-test, $t=4.05$, df $=18, \mathrm{p}<$ 0.001, Fig. 7B).

The time to first appearance of distinct sweeper tentacles in this experiment was $29.8 \pm 13.1 \mathrm{~d}$, and the time to reach maximal tentacle length was $52.0 \pm$ $11.6 \mathrm{~d}$. The length of feeding tentacles was $0.59 \pm$ $0.07 \mathrm{~cm}$, while sweeper tentacles were $3.9 \pm 1.7 \mathrm{~cm}$ long at full development (range $=2.0$ to $6.5 \mathrm{~cm}$ ), about $10 \times$ longer than feeding tentacles (at their maximal length in the laboratory). Each experimental colony of Platygyra daedalea developed $24.7 \pm 7.4$ sweeper tentacles ( $\mathrm{N}=9$ colonies). However, this number is an underestimate because the sweeper tentacles were transparent, moved constantly, and contracted when illuminated, making it difficult to count them accurately.
Tissue damage was observed for 9 out of 10 colonies of Favites complanata on the area facing experimental colonies of Platygyra daedalea; 1 colony of F. complanata that was not damaged also developed sweeper tentacles along the region of contact and, in turn, caused massive damage to its contact-colony of $P$. daedalea (Fig. 1C). In most cases, damage in the form of necrotic tissue began to appear on F. complanata colonies during the first week of the experiment. Bare skeleton began to appear approximately 2 wk following the start of contact. The area of damage on F. complanata colonies increased up to Day 63 of the experiment and then leveled off (Fig. 6).

\section{DISCUSSION}

We have shown here that a substantial proportion of colonies of the brain coral Platygyra daedalea contact neighboring corals on a reef at Eilat, and that many of them bear elongated sweeper tentacles. We have also demonstrated that these specialized tentacles may be induced to develop following contact with other corals, and that they cause massive tissue damage to opponents in most cases. Many brain corals in the field also possessed sweeper tentacles at random locations on the colony, not facing toward coral competitors. The common occurrence of sweeper tentacles on these corals, both randomly-located and directed toward adjacent corals, may in part explain the dominance of $P$. daedalea colonies on the reef examined.

Our study site in the northern Red Sea was an area with low topographical relief that contained a carpet of corals growing on metamorphic rock, rather than a well-developed coral reef. The faviid carpet is the most common type of coral carpet community in the northern Gulf of Aqaba, and consists mainly of the coral genera Goniastrea, Favia, Favites, Platygyra, Leptastrea, Cyphastrea, and Echinopora (Riegl \& Piller 1999). Our observations revealed a faviid carpet at the site in Eilat, in which the coral genera interacting most commonly with Platygyra daedalea were the above, plus colonies of the coral Stylophora pistillata (Fig. 2A).

Colonies of Platygyra daedalea appear to be moderately aggressive corals, ranked slightly higher than medium (10 on a scale of 1 to 17 , with 17 as highest) in an aggressive hierarchy of stony corals at Eilat (Abelson \& Loya 1999). Here we observed that most of the corals in contact with colonies of P. daedalea (Fig. 3A) were members of subordinate species (Abelson \& Loya 1999). Thus, it is not surprising that in almost half of all interactions they exhibited tissue damage, while in relatively few cases $(<9 \%)$ damage was observed in the brain corals (see 'Results'). Interestingly, individuals of Pocillopora spp. were ranked higher than 
Platygyra spp. by Abelson \& Loya (1999), but in 3 of 7 interactions with $P$. daedalea observed here, they suffered tissue damage, while in 1 case the damage was mutual. Pocillopora spp. also were considered to be highly aggressive by Sheppard (1979), but Platygyra spp. were not mentioned, and Abelson \& Loya (1999) observed only 2 interactions between colonies of the genera Pocillopora and Platygyra. Thus, sample sizes in published studies to date have been so low that no clear conclusions can be drawn concerning dominance between members of these 2 coral genera.

Sheppard (1981) reported that the aggressive reach of Platygyra daedalea in the Indian Ocean was 2.0 to $3.8 \mathrm{~cm}$; in contrast we observed a longer reach of $5.3 \pm$ $3.0 \mathrm{~cm}$, which is consistent with the sweeper tentacle lengths also observed here $(2$ to $11 \mathrm{~cm})$. Maximum sweeper tentacle length was approximately double that of mean aggressive reach.

At $>3 \mathrm{~cm}$ inter-skeletal distance, we found a significant decrease in the percent of coral colonies adjacent to Platygyra daedalea with tissue damage, so the effectiveness of sweeper tentacles appears to decrease with increasing distance, even within their range of extension (up to $11 \mathrm{~cm}$ ). Although sweeper tentacles have some ability to move actively, most of their movement appears to be passive via currents (Richardson et al. 1979, Wellington 1980, E. D. Lapid pers. obs.), which may deflect them and reduce their effectiveness with increasing distance from the colony (Genin \& Karp 1994). Turbulence created by surface waves in the shallow reef zones (Sebens \& Johnson 1991) inhabited by most colonies of Platygyra spp. also may not allow full extension of sweeper tentacles. We propose that longer sweeper tentacles which project further away from the colony surface are easier to deflect, since they are exposed to stronger flow (i.e. the border-layer effect in Shashar et el. 1996), and therefore are not much more effective than somewhat shorter tentacles in causing tissue damage to adjacent corals.

We have shown here, that in Platygyra daedalea, most sweeper tentacles occur on areas of colonies that face coral competitors, but that almost a quarter of the examined colonies possessed some sweeper tentacles at random locations that were not directed toward nearby corals. This suggests a possible pre-emptive, defensive function of sweeper tentacles in addition to their aggressive action, as also proposed by Richardson et al. (1979). The sweeper tentacles of $P$. daedalea can be $>10 \times$ longer than feeding tentacles, so they may act as a barrier to prevent the tentacles of opponents from getting too close to their vital organs and causing damage. Night observations revealed sweeper tentacle 'fights' between $P$. daedalea and some species of neighboring corals, in which both competitors expanded fully-developed sweepers across a wide gap between the colonies, and both appeared to avoid tissue damage. These observations raise an alternate hypothesis concerning the stimuli for sweeper tentacle development, in which no external environmental stimuli are necessary. We propose that some sweeper tentacles may develop at random locations on these coral colonies as a probe to detect the advance of cnidarian competitors and prevent them from growing closer, thus creating a wide coral-free buffer-zone. Following detection of coral competitors, species recognition may result in different numbers of sweeper tentacles being developed toward different types of opponent corals, which would explain the non-random patterns that we observed here (Fig. 3). In addition, the known ability of sweeper tentacles to revert back to feeding tentacles (den Hartog 1977, Wellington 1980) may explain in part why almost half the corals interacting with $P$. daedalea exhibited tissue damage, while in relatively few interactions, sweeper tentacles were observed (Fig. 3). When enough space has been evacuated (i.e. enough tissue killed on the neighbor), there may be little advantage to brain corals in the maintenance of long, specially-equipped tentacles that are likely to exert an energetic cost.

Our laboratory observations revealed a second mechanism of competition by Platygyra daedalea, mesenterial filaments, which were everted within hours to days after initial contact. These killed the tissues of opponents for up to $18 \mathrm{~d}$ into the experiment, and sometimes were conspicuous even when corals were contracted during the daytime. This behavior has not been observed for Platygyra spp. corals in the field, presumably because it is difficult to detect the period of initial contact, since corals grow slowly toward each other on the reef.

We suggest that sweeper tentacles are a common competitive mechanism on coral reefs, and are used by many more coral species than those summarized by Williams (1991). In addition to those mentioned in his review, members of 5 more genera of stony corals have been observed to develop sweeper tentacles: Platygyra (Langmead \& Chadwick-Furman 1999), Goniastrea (Abelson 1987), Acanthastrea, Favia and Favites (E. D. Lapid pers. obs. during present study, Fig. 1C). Some, if not all, members of these coral genera probably have the potential to develop sweeper tentacles, thus making it a common mechanism of coral defense/ aggression on some coral reefs.

We observed sweeper tentacles to develop on colonies of Platygyra daedalea after approximately 1 mo following initial contact with competitors; this is consistent with times to development known for other coral species. The stalks of fully-developed sweeper tentacles lack the batteries of nematocysts that occur on feeding tentacles. However, in some cases tentacles 
possessed similar features to sweepers, but also had nematocyst batteries. Taking into account all the parameters examined (ectoderm thickness at tip and stalk and width of tentacle at tip and stalk), PCA (principal components analysis) did not reveal 2 distinct populations of tentacles. Thus, sweeper tentacles with clear nematocyst batteries may be an intermediate stage in their development, although not all sweeper tentacles were observed to pass through it. Some tentacles began to widen before they elongated, and lost their nematocyst batteries at this stage.

In our experiment, sweeper tentacles formed mainly in the interaction zone between colonies, and up to several centimeters from this zone. However, it was impossible to determine exactly which polyps developed them. Platygyra daedalea is a meandroid coral, so it was not possible to determine the number of converted tentacles per polyp, as done by Sebens \& Miles (1988) for the octocoral Erythropodium caribaeorum. It appeared that, in general, tentacles were modified on adjacent polyps in $P$. daedalea.

We have presented here the first quantification of acrosphere development in the sweeper tentacles of stony corals, and have revealed a more extensive widening of the tentacle tip (doubling of the tip-tostalk ratio: Fig. 7A) than that reported during bulbous marginal tentacle development in corallimorpharians ( $<30 \%$ increase of the tip-to-stalk ratio: Langmead \& Chadwick-Furman 1999). The morphological basis for this change also differs between the 2 groups, in that it occurs via a large increase in ectoderm thickness in corallimorpharians, while in brain corals we observed only limited ectoderm-thickening (Fig. 7B), accompanied by a large increase in the internal cavity volume of the tentacle tip. We observed some variation between tentacles in the order of events during the morphogenetic process. Loss of nematocyst batteries is usually followed by elongation of the tentacles, but sometimes elongation precedes loss. During morphogenesis, the tentacles lose their tapered nature, become up to $20 \times$ longer (at maximal length observed in the field), and develop bulbous swollen tips and a thicker ectoderm.

We observed that both eversion of mesenterial filaments and subsequent development of sweeper tentacles were deployed by colonies of Platygyra daedalea towards those of Favites complanata, in contrast to previous reports that sweeper tentacles developed as a response to mesenterial wounds created by competitors (Richardson et al. 1979, Wellington 1980, Chornesky 1983). The time scale of our observations is consistent with past observations that the first contact between corals results in a mesenterial fight, as first shown by Lang (1971). Approximately 20 d after initial contact, mesenterial filaments were no longer observed. After sweeper tentacles developed, no more eversion of mesenterial filaments occurred, and the sweepers were used as the aggressive organs.

We propose that, although the main trigger of sweeper tentacle morphogenesis appears to be external (recognition of the soft tissues of certain other species of scleractinians), there may be also an internal stimulus that results in pre-emptive development of some sweeper tentacles even when neighboring corals are not present. This defensive behavior allows these brain corals to detect and damage newly-settled or encroaching neighbors at some distance from the colony, and results in a wide area of cleared space around most brain corals in the field (N.E. ChadwickFurman pers. obs.). We conclude that the agonistic mechanism of sweeper tentacles functions in both coral aggression and defense, and is similar to the defensive tactics used by sessile marine organisms in other types of benthic hard-substratum habitats (Karlson 1999). Thus, sweeper tentacle development appears to play a role in competition between many types of stony corals, and allows some slow-growing massive species to persist and dominate in certain coral reef habitats.

Acknowledgements. The authors would like to thank G. Ayalon and A. Levi, the former and current head aquarists of the Underwater Observatory Marine Park in Eilat respectively, for use of their facilities and water system. We thank S. Einbinder for helping with identification of the corals. Special thanks to Y. Bellmaker for collaboration in the photography, and for use of his digital camera. We thank B. George and all the students at the IUI who helped in night measurements. Special thanks to O. Ben-Shafrut. Funding was provided by a grant to N.E.C.-F. from Bar Ilan University. This work was submitted in partial fulfillment of the requirements for the MSc degree to E.D.Lapid at Bar Ilan University.

\section{LITERATURE CITED}

Abelson A (1987) Aggressiveness in stony corals: is it competition for space? MSc dissertation, Tel Aviv University

Abelson A, Loya Y (1999) Interspecific aggression among stony corals in Eilat, Red Sea: a hierarchy of aggression ability and related parameters. Bull Mar Sci 65:851-860

Benayahu Y, Loya Y (1981) Competition for space among coral reef sessile organisms at Eilat, Red Sea. Bull Mar Sci 31:514-522

Chadwick NE (1988) Competition and locomotion in freeliving fungiid coral. J Exp Mar Biol Ecol 123:189-200

Chornesky EA (1983) Induced development of sweeper tentacles on the reef coral Agaricia agaricites: a response to direct competition. Biol Bull (Woods Hole) 165:569-581

Connell JH (1973) Population ecology of reef building corals. In: Jones OA, Endean R (eds) Biology and ecology of coral reefs. Vol 2. Biology, Academic Press, New York, p 205-245

Connell JH (1976) Competitive interactions and the species diversity of corals. In: Mackie GO (ed) Coelenterate ecology and behavior. Plenum Press, New York, p 51-58

Cope M (1981) Interspecific coral interactions in Hong Kong. Proc 4th Int Coral Reef Symp 1:357-362 
den Hartog JC (1977) The marginal tentacles of Rhodactis sanctithomae (Corallimorpharia) and the sweeper tentacles of Montastrea cavernosa (Scleractinia) their cnidom and possible function. Proc 3rd Int Coral Reef Symp 1: 463-469

Genin A, Karp L (1994) Effects of flow on competitive superiority in scleractinian corals. Limnol Oceanogr 39:913-924

Glassom D (2002) Reproductive ecology and reef dynamics: a study on coral at Eilat, northern Red Sea. PhD dissertation, Bar-Ilan University, Ramat Gan

Goldberg WM, Grang KR, Taylor GT, Zuniga AL (1990) The structure of sweeper tentacles in the black coral Antipathes fiordensis. Biol Bull (Woods Hole) 179:96-104

Hidaka M, Yamazato K (1984) Interspecific interactions in a scleractinian coral Galaxea fasicularis: induced formation of sweeper tentacles. Coral Reefs 3:77-85

Karlson RH (1999) Dynamics of coral communities. Kluwer Academic, London

Lang J (1970) Inter-specific aggression within the scleractinian reef corals. PhD Dissertation, Yale University, New Haven, CT

Lang J (1971) Interspecific aggression by scleractinian corals. 1. The rediscovery of Scolymia cubensis (Milne Edwards \& Haime). Bull Mar Sci 21:952-959

Lang J (1973) Interspecific aggression by scleractinian corals. 2 . Why the race is not only to the swift. Bull Mar Sci 23: $260-279$

Lang JC, Chornesky EA (1990) Competition between scleractinian reef corals: a review of mechanisms and effects. In: Dubinsky Z (ed) Ecosystems of the world. Vol 25. Coral reefs, Elsevier, Amsterdam, p 209-252

Langmead O, Chadwick-Furman NE (1999) Marginal tentacles of the corallimorpharian Rhodactis rhodostoma. 2. Induced development and long term effects on coral competitors. Mar Biol 34:491-500

Lewis JB (1975) Feeding mechanisms and feeding strategies of Atlantic reef corals. J Zool 176:527-544

Miller KJ, Benzie JAH (1997) No clear genetic distinction between morphological species within the coral genus Platygyra. Bull Mar Sci 61:907-917

Peach MB, Guldberg OH (1999) Sweeper polyps of the coral Goniopora tenuidens (Scleractinia: Poritidae). Invertebr Biol 118:1-7

Editorial responsibility: Otto Kinne (Editor), Oldendorf/Luhe, Germany
Porter JW (1974) Community structure of coral reefs on opposite sides of the Isthmus of Panama. Science 186:543-545

Purkis S, Riegl B (2004) Spatial and temporal dynamics of Arabian Gulf coral assemblages quantified from remotesensing and in situ monitoring data (Jebel Ali, Dubai, UAE). Mar Ecol Prog Ser (in press)

Richardson CA, Dustan P, Lang JC (1979) Maintenance of living space by sweeper tentacles of Montastrea cavernosa, a Caribbean reef coral. Mar Biol 55:181-186

Riegl B, Piller WE (1999) Coral frameworks revisited-reefs and coral carpets in the northern Red Sea. Coral Reefs 18: 241-253

Romano SL (1990) Long-term effects of interspecific aggression on growth of the reef-building corals Cyphastrea ocellina (Dana) and Pocillopora damicornis (Linnaeus). J Exp Mar Biol Ecol 140:135-146

Sebens KP, Johnson AS (1991) Effects of water movement on prey capture and distribution of reef corals. Hydrobiologia 226:91-101

Sebens KP, Miles JS (1988) Sweeper tentacles in a gorgonian octocoral: morphological modifications for interference competition. Biol Bull (Woods Hole) 175:378-387

Shashar N, Kinane S, Jokiel PL, Patterson MR (1996) Hydromechanical boundry layers over a coral reef. J Exp Mar Biol Ecol 199:17-28

Sheppard CRC (1979) Interspecific aggression between corals with reference to their distribution. Mar Ecol Prog Ser 1: $237-247$

Sheppard CRC (1981) 'Reach' of aggressively interacting corals, and relative importance of interactions at different depths. Proc 4th Int Coral Reef Symp 2:363-368

Sheppard CRC, Sheppard ALS (1991) Corals and coral communities of Arabia. Fauna Saudi Arabia 12:1-165

Veron JEN (1986) Corals of Australia and the Indo-Pacific. University of Hawaii Press, Honolulu, HI

Veron JEN (2000) Corals of the world. Australian Institute of Marine Science, Townsville

Wellington GM (1980) Reversal of digestive interactions between Pacific reef corals: mediation by sweeper tentacles. Oecologia 47:340-343

Williams RB (1991) Acrorhagi, catch tentacles and sweeper tentacles: a synopsis of aggression of actiniarian and scleractinian cnidaria. Hydrobiologia 216/217:539-545

Submitted: February 20, 2004; Accepted: July 8, 2004 Proofs received from author(s): November 8, 2004 